\title{
Multilateralism in US Coercive Diplomacy to North Korea
}

\author{
D Mutmainah ${ }^{1}, N_{\text {Nurmalitasari }}{ }^{2}$, M Farayunand $^{3}$ \\ 1,2,3 Universitas Brawijaya, Malang \\ 1. $\underline{\text { dian.mutmainah@gmail.com, }}, \underline{{ }^{2} \text { nindhitya.n@gmail.com, }}, \underline{{ }^{3} \text { m.farayunand@gmail.com }}$
}

\begin{abstract}
This article discusses how both coercer and target states are using multilateral forums in the dynamic of coercive diplomacy. This research was intended to elaborate further the role of international aspect in the study of coercive diplomacy. International factor is considered as important in coercive diplomacy because other states' support will determine the strength of both coercer state's strategy and target state's counterstrategy. However, this aspect is only one of some elements that altogether will affect the success of a coercive diplomacy. Interestingly, some cases have proven that international environment can be pivotal in determining the result of the action. This research confirmed that both the United State (US) and North Korea have been using multilateral forums to support their causes as coercer state and target state related to North Korea denuclearization. The US has mainly been using the United Nations (UN), Six Party Talks, ASEAN Regional Forum (ARF), and World Food Program (WFP) to support its coercive actions on North Korea. Meanwhile, North Korea mostly has been using Six Party Talks and WFP to counter US's pressures. Indeed, North Korea has strategically used both forums to cover its domestic weaknesses in support of its counterstrategy to US coercive diplomacy.
\end{abstract}

Keywords: Multilateralism, Coercive Diplomacy, US, North Korea

\section{INTRODUCTION}

Coercive diplomacy is a diplomatic mechanism conducted by a state to provide pressures to other state in order to make the targeted state comply with certain arrangement. Bruce Jentleson defines coercive diplomacy as "... a diplomatic strategy with a degree of limited coercion [1]." In order to generate such coercion, coercive diplomacy is using both carrots and stick all together including economic sanctions and military force. However, coercive diplomacy was not intended to wage war. Indeed, a war is an indicator of failure in coercive diplomacy.

The use of coercive instruments in coercive diplomacy is aimed to gain credibility for the coercive actions taken towards the target state. Jentleson stated that:

"Coercive diplomacy applies pressure in a manner and magnitude that seeks to persuade an opponent to cease aggression rather than bludgeon him into stopping...just enough force of an appropriate kind to demonstrate resolution and to give credibility to the threat that greater force will be used if necessary [2]." 
This means that coercive diplomacy is using threats as intimidating instrument to generate compliance behavior of the target state. Threats need to be used proportionally so that the pressures is not too much that sufficiently trigger a war. Among various factors, international support is one of the most important factors that determine the success of coercive diplomacy. Therefore, multilateral forums and mechanisms are usually used and created to gather international solidarity towards the coercive action.

US coercive diplomacy towards North Korea has been performed for a long time. There were various kind of pressures the US has been applied towards North Korea: imposing economic sanctions to North Korea since Korean War in 1950s by stopping all import from North Korea; inserting North Korea into the list of excluded country in International Traffic in Arms Regulations (ITAR) in 1955; inserting Noth Korea into terrorist-sponsoring country in 1988; and freezing various North Korean entities' activities abroad that were claimed as violating Nuclear Non-Proliferation Treaty (NPT) [3].

International pressures to North Korea were intensified in 1990s onwards as North Korea keep resuming its nuclear activities. As a response, International Atomic Energy Agency (IAEA) announced that North Korea has violated NPT in 1993 [4]. North Korea continuing nuclear development activities also broke its reconciliation commitment with South Korea. Instead of return to the commitment, North Korea responded that action by withdrew itself from both the NPT and IAEA [5].

US has been the most active country to impose both unilateral or multilateral sanctions to North Korea as a pressure to stop its nuclear development programa. US approach was changing from unilateralism to multilateralism. US important unilateral action through Agreed Framework (1994) was ended in 2002 and replaced with multilateral talks called as Six-Party Talk since 2003. Six-Party Talk become the only specific multilateral forums on North Korea denuclearization.

\section{RESEARCH METHOD}

This study used process-tracing approach to investigate how both US and North Korea using multilateral forums to support their position towards North Korea de denuclearization. The object of this study is the multilateral forums used by the US as a coercer state to change North Korea behavior towards its nuclear development and by North Korea to counter it. The data were obtained through literary study by gathering data from secondary resources that are relevant to the purpose of the study. The collected data was analyzed using interactive analysis model that consists of four stages (data collection, data reduction, data display and drawing conclusion) [6]. This research was focusing the case in the periods of $1990 \mathrm{~s}-2013$.

\section{RESULTS AND DISCUSSION}

As Jentleson said, international support is important to create pressures upon targeted state in a coercive diplomacy. This is possible only when the issue has raised international concerns. North Korea nuclear development has been acknowledged as an international security issue and has been put into UN Security Council agenda. That means North Korea nuclear issue has been internationally admitted as threatening.

The US has been using various international forums to gain international supports to suppress North Korea intention to develop nuclear. These are the list of multilateral forums has been used by the US to both raise the issue and provide collective arrangement to stop North Korea nuclear development. 
Table 1. Multilateral Forums Used by the US to Gain International Support in North Korea Denuclearization

\begin{tabular}{|c|c|c|}
\hline $\begin{array}{l}\text { Multilateral } \\
\text { Forum }\end{array}$ & Periods & Results \\
\hline $\begin{array}{l}\text { Six Party Talks } \\
\text { (Armscontrol.org, } \\
\text { 2015; US } \\
\text { Department of } \\
\text { State, 2015) }\end{array}$ & 2003 - Current & $\begin{array}{l}\text { Deadlock. Until 2008, there is no new consensus } \\
\text { has been resulted after North Korea decided to } \\
\text { reactivated its nuclear production which was also } \\
\text { violated its agreement with the US in October } \\
2007 \text { as part of the sixth round negotiation in Six- } \\
\text { Party Talks. }\end{array}$ \\
\hline UNSC & 2006 - Current & $\begin{array}{l}\text { Since 2006, UNSC has declared several UNSC } \\
\text { Resolution to condemn and sanction North Korea } \\
\text { regarding its nuclear weapon production and } \\
\text { trials. }\end{array}$ \\
\hline WFP & 1995 - Current & $\begin{array}{l}\text { WFP has been enclosed to the dynamic of North } \\
\text { Korea nuclear negotiation in other forums because } \\
\text { the results tend to impact the life of North Korean } \\
\text { citizen who depend on international help to } \\
\text { provide food in crisis. }\end{array}$ \\
\hline $\begin{array}{l}\text { ASEAN Regional } \\
\text { Forum }\end{array}$ & $\begin{array}{l}1996- \\
\text { Intensify in } \\
2012-13\end{array}$ & $\begin{array}{l}\text { Indirect, but important to make sound of the US } \\
\text { coercive credibility. }\end{array}$ \\
\hline
\end{tabular}

Source: Extracted from various sources.

Among those multilateral forums, Six-Party Talks and UNSC were the main forums used by the US to press North Korea by creating multilateral arrangement for denuclearization. Meanwhile, WFP played a unique role as the forum where the strategic intention of a difficult negotiation clashed with humanitarian responsibility towards North Korean citizen. As for ARF, the forum has been used by both sides to promote how nonproliferation regime should be treated. Here is the detail.

\section{a. Six Party Talks}

Six Party Talks is multilateral forum initiated in George W. Bush era (2003) which replacing the previous bilateral strategy applied during Clinton's administration through Agreed Framework 1994 [7]. Until 2013, there were $6^{\text {th }}$ round of talks between North Korea and the US, Russia, China, South Korea, and Japan has been conducted through Six Party Talks. However, until the $6^{\text {th }}$ round conducted in 2008, there were no success as North Korea keep violating agreements that have been generated during 2003-2008.

Table 2. Six Party Talks Rounds and Its Results

\begin{tabular}{cll}
\hline Round & \multicolumn{1}{c}{ Date } & \multicolumn{1}{c}{ Result } \\
\hline Round I & 27 August 2003 / & No significant agreement as US rejected North Korea \\
& Beijing, PRC & $\begin{array}{l}\text { requests for normalization and non-aggression pact with } \\
\text { the US. As a response, North Korea stated that it will } \\
\end{array}$ \\
& & $\begin{array}{l}\text { continue its nuclear trial. However, there was a } \\
\text { commitment for a future dialogue in settling the issue. }\end{array}$ \\
\hline
\end{tabular}




\begin{tabular}{|c|c|c|}
\hline Round II & 25 February 2004 & $\begin{array}{l}\text { No important agreement achieved, just reinstated the } \\
\text { commitment to create "nuclear-weapons-free Korean } \\
\text { peninsula." This time, Chinese and Russian negotiators } \\
\text { took a more active part and successfully made North } \\
\text { Korea to offer its commitment to halt its nuclear weapon } \\
\text { development while continuing nuclear development for } \\
\text { peaceful purpose. But this offer was rejected by the US, } \\
\text { Japan, and South Korea that thought that the program } \\
\text { should be totally stopped. }\end{array}$ \\
\hline Round III & 23th June 2004 & $\begin{array}{l}\text { No agreement achieved. US and South Korea offered } \\
\text { proposal to freeze North Korea nuclear program, but } \\
\text { North Korea asked for compensation. Unfortunately, no } \\
\text { consensus achieved since uncertainty was high as US } \\
\text { facing election in the middle of negotiation. }\end{array}$ \\
\hline Round IV & $\begin{array}{l}26 \text { Juli }-7 \\
\text { August } 2005 \& \\
13-19 \text { September } \\
2005 \text { / Beijing, } \\
\text { PRC }\end{array}$ & $\begin{array}{l}\text { A joint statement to denuclearize North Korea was } \\
\text { signed. US were softened and North Korea agreed to } \\
\text { return both to NPT and IAEA. All parties agreed to } \\
\text { provide energy supply for North Korea and planning } \\
\text { light water reactor development in return to its } \\
\text { denuclearization commitment. }\end{array}$ \\
\hline \multirow[t]{2}{*}{ Round V } & 9 November 2005 & $\begin{array}{l}\text { No continuation was resulted as a consequence for the } \\
\text { previous joint statement. Instead, US sanctions to North } \\
\text { Korea trade entities and Banco Delta Asia Makau has } \\
\text { raised provocations to boycott Six Party Talks and redo } \\
\text { missile test in } 2006 \text {. }\end{array}$ \\
\hline & February 2007 & $\begin{array}{l}\text { Discussion on the implementation of Joint Statemen } \\
2015 \text { was continued. An agreement was achieved, there } \\
\text { were commitments on: deactivation steps of Yongbyon } \\
\text { nuclear facility in } 60 \text { days. In return, other parties } \\
\text { committed to provide } 50.000 \text { ton heavy fuel oil during } \\
\text { those } 60 \text { days. The US also committed to withdraw } \\
\text { North Korea from both US critical lists (terrorism- } \\
\text { sponsoring country and Trading with the Enemy Act). } \\
\text { However, those commitments were unfulfilled in the } \\
\text { next round. }\end{array}$ \\
\hline \multirow[t]{4}{*}{ Round VI } & $2007-2008$ & $\begin{array}{l}\text { Previous agreements were broken down as both sides } \\
\text { withdrew their commitments in the agreement. }\end{array}$ \\
\hline & 9 March 2007 & $\begin{array}{l}\text { North Korea walked out as US delayed to unfreeze North } \\
\text { Korea assets as a consequence of sanction to Banco Delta } \\
\text { Asia. }\end{array}$ \\
\hline & $\begin{array}{l}\text { September- } \\
\text { October } 2007\end{array}$ & $\begin{array}{l}\text { Both sides were agreed to implement the second phase of } \\
\text { denuclearization. }\end{array}$ \\
\hline & June 2008 & $\begin{array}{l}\text { North Korea declared the halting of nuclear activities. } \\
\text { Bush announced the withdrawal of North Korea from } \\
\text { negative list. } \\
\text { But, North Korea changed its mind and stated that it will } \\
\text { reactivate its nuclear reactor. Renegotiation and re- }\end{array}$ \\
\hline
\end{tabular}




\begin{tabular}{lll}
\hline & & $\begin{array}{l}\text { agreement was verbally reached, but failed to implement } \\
\text { after all. }\end{array}$ \\
\cline { 2 - 3 } $8-11$ & December & A Six Party Talks session was conducted, but \\
2008 & $/$ Beijing, & there was no consensus or result was achieved. \\
PRC & & \\
\hline
\end{tabular}

Sources: Extracted from Armscontrol.org (2015), US Department of State (2015)

There were no other Six Party Talks formal forums after North Korea resumed its missile trial in 2009. In 14 April 2009, North Korea officially stated that it will not participate again in Six Party Talks and declared that it is not bound by any previous agreements [7]. US, China, and Russia had been trying to push another Six Party Talks meeting, but none was successful until 2013. A meeting between North Korea and South Korea in the middle of ASEAN meeting in Bali (22 Juli 2011) and a meeting between US and North Korea in Geneva (October 2011) were both failed to reactivate Six Party Talks [7]. So, there is no Six Party Talks meeting again until 2013.

\section{b. United Nations Security Council (UNSC)}

UNSC has been the main forum used by the US to gather wider international support to stop North Korea nuclear development. During 2006-2013, there were five UN resolutions declared by UNSC towards North Korea regarding its nuclear development activities (Resolution 1695, 1718, 1874, 2087, and 2094). Actually, UN resolution on North Korea nuclear proliferation was adopted since Korean War in 1950s [3]. In general, those resolutions indicated that all five permanent members of UNSC agreed to impose sanctions to North Korea in order to support its denuclearization. Among all members, China has shown its reluctance to support any additional sanctions to North Korea [8]. Meanwhile, US were the most active and aggressive one in pursuing sanctions against North Korea through UNSC [3].

\section{c. ASEAN Regional Forum (ARF)}

ARF was an indirect access for the US to gather international support from Southeast Asian countries. ARF became an arena for US to spread nonproliferation norms by committing supports towards UN Resolutions on North Korea nuclear issue. These especially intensified in 2012 and 2013 ( $4^{\text {th }}$ and $5^{\text {th }}$ ARF meeting) after North Korea conducted missile trials [9].

\section{d. World Food Programme (WFP)}

WFP has been an interesting institution used by the US to coerce North Korea by offering food aid as part of concession in nuclear negotiation. Actually, WFP is one of UN institutions operating in North Korea during crisis besides FAO, UNFPA, UNICEF, and WHO [10]. WFP has been supplying humanitarian aid to North Korea since 1995 after North Korea suffered serious hunger disaster [11]. Lack of food supplies in North Korea were worsened by flood in 1996 and long dry season in 1997 which made harvesting is impossible [12].

US is one of the main food aid donors to North Korea besides China, South Korea, and Japan. Besides WFP, US was also using NGOs to deploy its food aid to North Korea. The NGOs are: World Vision, Mercy Corps, Samaritan's Purse, Global Resource Services dan Christian Friends of Korea. However, 90 \% of US food aid to North Korea were deployed through WFP [13].

US has been using food aid to negotiate with North Korea on its nuclear development. However, it did not work well since other states can stay as donor when US withdraw its food aid. In 2006-7, US stopped its food aid to North Korea after North Korea's first trial on nuclear weapon in 2006. During 2006-8, North Korea accepted food aid through bilateral mechanisms. Mostly from China and South Korea. But in 2008, North Korea requested for food aid again to WFP as bilateral aid from China and South Korea shortened [14]. In 2008, WFP and the US 
resumed aid to North Korea as the level of hunger was worsened. But, the aid was stopped again in 2009 after North Korea resumed its missile trial. In 2012, Obama withdraw its comitment to deploy food aid after North Korea resumed its nuclear trial.

For North Korea, multilateral forums are important to display its disagreement towards US's stance on its nuclear development. This normative intention was especially carried through UNSC and ARF. Meanwhile, Six Party Talks has been used by North Korea to reopen its economic access as most economic sanctions were orchestrated by the US through this forum. That is why several momentum were broken down because North Korea withdrew its previous commitments when US and other states failed to accomplish their commitment to lift sanctions. North Korea has always been using nuclear trials to demonstrate its incompliance.

As for WFP, North Korea has been routinely using it to overcome food crisis in the country. North Korea liked bilateral mechanism rather than multilateral one like WFP to get food aid. Multilateral mechanism opened the chance to provide international acces to North Korea as a requirement. North Korea had a tendency to choose bilateral aid from China and South Korea when it wanted to avoid multilateral acces for international communities to North Korea. North Korea will accept or request multilateral mechanism like WFP when bilateral food aid was not available. US is the biggest aid donor in WFP. US also provide food aid for North Korea though bilateral mechanism, especially through US NGOs. US was cancelled its supply in 2008 and 2012 after North Korea resumed its missile launching which was violated agreement at that time [15]. However, its was proven that US major contribution in WFP did not generate domination towards North Korea nuclear program.

GRAPHIC 1. WFP Food Aid Allocation to North Korea (1995-2012) [11]

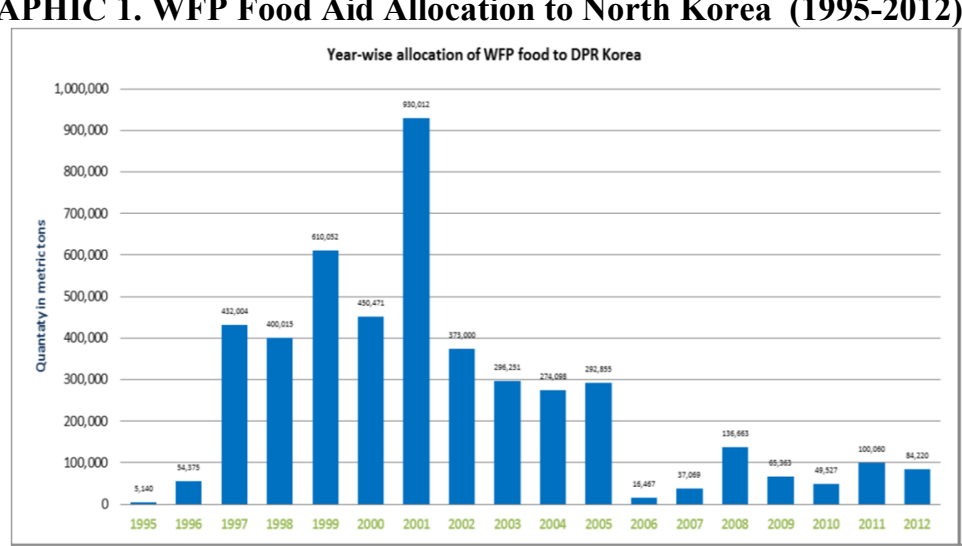

Source: WFP Factsheet (2013)

WFP has been the forum where North Korea can get food aid for its citizen in hunger without necessarily fulfill its commitment to stop its nuclear as food aid cannot only be given based on rational consideration related to nuclear negotiation [15]. Food crisis has made WFP need to hold up humanity towards North Korean citizen. From Graphic. 1, we can see that even when US stopped its aid, WFP kept on supplying food aid to North Korea.

\section{CONCLUSIONS}

Multilateralism had both positive and negative impact to the effectiveness of a coercive diplomacy. The forums (Six Party Talks, UNSC, ARF, and WFP) have generated different impact to US coercive diplomacy to North Korea. UNSC and Six Party Talks are the 
most effective forums to raise credibility to US coerces. Meanwhile, ARF is effective is terms of creating containment environment for the idea to develop nuclear not in accordance with the NPT regime. WFP is the most interesting forum that showing that not every multilateral forums can be used by dominant state to press other states. It was proven that WFP could not fully support the idea to sanction North Korea as its main responsibility was to overcome hunger in North Korea. So, when US and other negotiating parties like China and South Korea stopped the aid, WFP still provide food aid for North Korea for its very basic principle. It is human rights. However, we cannot deny that the absence of dominant state participation did reduce WFP capacity to accomplish its responsibility.

\section{REFERENCES}

[1] ASEAN. "ARF Statement of Non-proliferation," Accessed: http://aseanregionalforum $\underline{\text { asean.org/library/arf-chairmans-statements-and-reports.html?id=179 }} \quad(10$ October 2015)

[2] Armscontrol.org. (2015). Accessed form: https://www.armscontrol.org/ factsheets/dprkchron (10 Oktober 2015)

[3] Britannica. (2015). Accessed form: http://www.britannica.com/topic/ASEAN-RegionalForum (10 Oktober 2015)

[4] Jentleson, B. (2006). "Coercive Diplomacy: Scope and Limits in the Contemporary World". Policy Analysis Brief. The Stanley Foundation.

[5] Jentleson, B. \& Whytock, C.A. 2006. "Who 'Won' Libya?: The Force-Diplomacy Debate and Its Implications for Theory and Policy”, International Security, Vol. 30, No. 3 (Winter 2005/06), pp. 47-86.

[6] Lee, K., \& Choi, J. (2009). North Korea: Unilateral and Multilateral Economic Sanctions and U.S. Department of Treasury Actions 1955-April 2009. The National Committee of North Korea.

[7] Manyin, M. E. \& Nikitin, M.B.D. (2014). Foreign Assistance to North Korea. Congressional Research Service (CSR), Library of Congress.

[8] New York Times. (2014). Accessed from: http:/www.nytimes.com/interactive/2014/11/20/world/asia/northkoreatimeline.html?_r=0/(5 September 2015)

[9] Niksch, L.A. (2015). North Korea's Nuclear Weapons Program. CRS Issue Brief for Congress (27 Januari 2015)

[10] M. B. Miles and A. M. Huberman, Analisis Data Kualitatif, Jakarta: UI Press, 1992.

[11] UN. (2015). Accessed from: http://kp.one.un.org/country-team/ (10 October 2015)

[12] US Department of State. (2015). Accessed from: http://www.state.gov/p/eap/regional/c15455.htm (10 October 2015)

[13] US Department of State. (2015). Accessed from: http://www.state.gov/p/eap/regional/c15455.htm (10 October 2015)

[14] WFP Report. (2000). A Report from the Office of Evaluation: Full Report of the Evaluation of DPRK EMOPs5959.00 and 5959.01"Emergency Assistance to Vulnerable Groups" 20 March - 10 April 2000. WFP. 
[15] WFP. (2013). WFP Factsheet 2013: Korea Utara. Accessed from: http://wfp.org.( (10 October 2015) 